\title{
Presence of selected pathogens on the gills of five wrasse species in western Norway
}

\author{
A. Steigen* ${ }^{*}$ A. Nylund, H. Plarre, K. Watanabe, E. Karlsbakk, Ø. Brevik \\ Department of Biology, University of Bergen, Bergen, Norway
}

\begin{abstract}
The objective of this study was to identify gill pathogens in Labridae (wrasse) species used as cleaner fish to control salmon louse in western Norwegian aquaculture. Wrasse are often moved over long distances, raising issues of fish health, welfare and pathogen transmission. Histological examination and real-time RT-PCR analysis of the gills from Centrolabrus exoletus, Ctenolabrus rupestris, Labrus bergylta, L. mixtus and Symphodus melops revealed several pathogens: a new species of Ichthyobodo, Paramoeba perurans, microsporidia, trichodinids, Hatschekia spp., Candidatus Similichlamydia labri and 2 putative new species of Chlamydiae. Cand. S. labri or closely related bacteria were present on most wrasse specimens. Epitheliocysts on the gills of $L$. mixtus contained large inclusions $(120 \mu \mathrm{m})$ with actiniae radiating from the inclusion membrane. A possible member of the Candidatus family Parilichlamydiaceae was present at a high prevalence on the gills of L. mixtus, L. bergylta and C. rupestris. Sequencing the 16S rRNA gene showed $93.9 \%$ similarity to Cand. S. labri and $96.8 \%$ similarity to Cand. Parilichlamydia carangidicola from the gills of Seriola lalandi. This bacterium probably represents a new species within the order Chlamydiales, family Cand. Parilichlamydiaceae. The other Chlamydiae detected on gills of $S$. melops could represent a new species in Cand. genus Syngnamydia. Ichthyobodo sp. and Paranucleospora theridion were detected on the gills of nearly all individuals, while Paramoeba spp. were detected on the gills of $L$. bergylta and L. mixtus. Trichodinids, microsporidia and parasitic copepods had low prevalence. Viral haemorrhagic septicaemia virus was not detected.
\end{abstract}

KEY WORDS: Labridae $\cdot$ Cleaner fish $\cdot$ Biocontrol $\cdot$ Salmon louse $\cdot$ Ichthyobodo Paramoeba Hatschekia spp. · Candidatus Similichlamydia labri · Microsporidia · Trichodinids · Fish welfare

\section{INTRODUCTION}

The salmon louse Lepeophtheirus salmonis, which feeds on mucus, skin and blood of its host, is a serious problem to farming of Atlantic salmon Salmo salar in Norway (Heuch et al. 2005). The reproduction of $L$. salmonis in salmon farms and the spread of larvae into the surrounding sea are also recognized as a threat to wild salmonids, namely S. salar and Salmo trutta, along the Norwegian coast (Krkošek et al. 2013). Several strategies, including the use of cleaner fish, are being employed to reduce the consequences of L. salmonis (Torrissen et al. 2013). Salmon farmers in western Norway are mainly using 4 wrasse species

\footnotetext{
*Corresponding author: andreas.steigen@bio.uib.no
}

(Labridae): rock cook Centrolabrus exoletus, goldsinny Ctenolabrus rupestris, ballan wrasse Labrus bergylta and corkwing wrasse Symphodus melops. Collection of wild wrasse species and culturing of $L$. bergylta for their use as cleaner fish, and movement of these species along the coast of Norway, raises questions about the health of wrasses in the wild and the possible transmission of pathogens between local wrasse populations. Cultured wrasse species may carry pathogens such as Paramoeba perurans and viral haemorrhagic septicaemia virus (VHSV); hence, movement of these wrasse species may represent a risk of introducing these pathogens into salmon cages (Karlsbakk et al. 2013, Munro et al. 2015,

() The authors 2018. Open Access under Creative Commons by Attribution Licence. Use, distribution and reproduction are unrestricted. Authors and original publication must be credited. 
Wallace et al. 2015). Other gill pathogens that may occur on the gills of wrasse species include parasitic copepods, monogeneans, trichodinids, flagellates, microsporidians and bacteria (Karlsbakk et al. 1996, Askeland 2002, Treasurer 2012).

Recently, 2 new Chlamydiae species, Candidatus Similichlamydia labri (family Cand. Actinochlamydiaceae) and Cand. Syngnamydia salmonis (family Simkaniaceae), associated with epitheliocystis, were described from the gills of $L$. bergylta and S. salar, respectively, expanding the number of species and geographical distribution of bacteria within the Chlamydiales (Nylund et al. 2015, Steigen et al. 2015). Epitheliocystis has been seen in a high number of fish species; in most cases, these show a chlamydia-like intracellular development and rRNA gene sequences, suggesting members of the order Chlamydiales (Paperna \& Sabnai 1980, Bradley et al. 1988, Crespo et al. 1990, Lewis et al. 1992, Nylund et al. 1998, Draghi et al. 2004, Nowak \& LaPatra 2006, Horn 2008, Karlsen et al. 2008, Polkinghorne et al. 2010, Corsaro \& Work 2012, Schmidt-Posthaus et al. 2012, Camus et al. 2013, Fehr et al. 2013, Steigen et al. 2013, 2015, Stride et al. 2013a,b,c, Nylund et al. 2015). Beta- and Gammaproteobacteria have also been connected to epitheliocystis in farmed fish (Toenshoff et al. 2012, Mendoza et al. 2013, Katharios et al. 2015, Contador et al. 2016, Seth-Smith et al. 2016), expanding the diversity of epitheliocystis agents.

To gain more knowledge on naturally occurring gill pathogens in different wrasse species, a study of selected pathogens was started in 2011. This study shows that Chlamydiae (several genetically distinct strains) and a putative new species of Ichthyobodo are relatively common on the gills of most wrasse species in western Norway. The morphology of epitheliocysts, the inclusions and the bacteria from $L$. mixtus are described and compared to Candidatus S. labri from L. bergylta (Steigen et al. 2015). The prevalence and occurrence of other pathogens such as Paramoeba spp., trichodinids, microsporidians and VHSV is also presented, and their potential importance for wild wrasse and farmed Atlantic salmon is discussed.

\section{MATERIALS AND METHODS}

\section{Fish}

Five different species of wrasse (Centrolabrus exoletus, Ctenolabrus rupestris, Labrus bergylta, L. mixtus and Symphodus melops) were collected during May and June 2012 in Raunefjorden close to Bergen, western Norway (Table 1). The fish were mature or had just spawned. A second sampling period was in October 2012 and a third was in May 2013. A small sample of L. mixtus was also collected in September 2014. The sampling was done using fyke nets, and live individuals were brought to the laboratory at the University of Bergen. All fish were treated according to the Norwegian Animal Welfare Act (01.01.2010), and all samples were taken from newly killed fish (Table 1). Tissues were fixed and preserved in Karnovsky fixative at $-4^{\circ} \mathrm{C}$, or stored for a very short period at $-20^{\circ} \mathrm{C}$ before extraction of RNA or DNA which was stored at $-80^{\circ} \mathrm{C}$. Samples for realtime reverse transcription (RT)-PCR and sequencing were taken from the first gill arch, while the second and third arches were used for histology.

The wrasse species were identified based on morphology, and the identity of a selection of these was confirmed by sequencing of the cytochrome oxidase subunit I gene (cox1, $448 \mathrm{nt}$ ) using the primers (bar coding) Cox-F1 (TAA AGA YAT TGG CAC CCT YWA TC) and Cox-R1 (GGA GGT TTC ATG TTA RYR ATG G). The primers were designed to match conserved regions using an alignment of all available Cox I sequences from wrasse.

\section{Inspection of gills for macroscopic and microscopic parasites}

The left side of the fish and the gill arches on the left side of all specimens were checked for presence of parasitic copepods (Caligus centrodonti, C. elongatus and Hatschekia sp.) and gross pathology. This was performed as a visual recording of the presence of these parasites on the skin and gills in situ. The parasites were identified using Kabata (1992). The numbers of these macroparasites on each individual and the prevalence among the fish sampled were not recorded. Microparasites were detected by real-time RT-PCR and histological examinations.

\section{Histology}

Gill tissues were fixed in Karnovsky fixative. The gill tissues from 15 specimens ( 3 ind. species ${ }^{-1}$ ) were processed as described by Steigen et al. (2013) and were used for histological studies and transmission electron microscopy. 
Table 1. Overview of material collected in 2012-2014: wrasse species, collection month, number (N), weight, length and the number of fish positive for the following: 2 different species of Chlamydiae (Candidatus Similichlamydia labri and Clade A), Ichthyobodo sp., and Paranucleospora theridion. All fish were also tested for viral haemorrhagic septicaemia virus, but none returned positive results

\begin{tabular}{|c|c|c|c|c|c|c|c|c|}
\hline Species & Month & $\mathrm{N}$ & Weight (g) & Length (cm) & Cand. S. labri & Clade A & Ich. sp. & P. theridion \\
\hline \multirow[t]{4}{*}{ Centrolabrus exoletus } & May 2012 & 8 & 21.4 & 12.1 & 8 & 0 & 7 & 8 \\
\hline & Jun 2012 & 13 & 24.9 & 11.8 & 13 & 0 & 13 & 12 \\
\hline & Jun 2013 & 4 & 22.5 & 11.8 & 4 & 0 & 4 & 4 \\
\hline & Total & 25 & & & 25 & 0 & 23 & 24 \\
\hline \multirow[t]{4}{*}{ Ctenolabrus rupestris } & May 2012 & 4 & 19.5 & 11.0 & 4 & 4 & 4 & 4 \\
\hline & Jun 2012 & 12 & 15.4 & 11.0 & 12 & 12 & 12 & 9 \\
\hline & May 2013 & 25 & 13.9 & 10.5 & 25 & 25 & 23 & 23 \\
\hline & Total & 41 & & & 41 & 41 & 39 & 33 \\
\hline \multirow[t]{4}{*}{ Labrus bergylta } & Jun 2012 & 44 & 349.1 & 27.7 & 44 & 39 & 39 & 39 \\
\hline & Oct 2012 & 4 & 33.7 & 31.0 & 4 & 4 & 4 & 4 \\
\hline & May 2013 & 15 & 205.0 & 23.9 & 15 & 15 & 15 & 2 \\
\hline & Total & 63 & & & 63 & 58 & 58 & 45 \\
\hline \multirow[t]{6}{*}{ L. mixtus } & May 2012 & 6 & 69.3 & 17.8 & 6 & 6 & 6 & 6 \\
\hline & Jun 2012 & 6 & 82.3 & 17.8 & 6 & 6 & 6 & 6 \\
\hline & Oct 2012 & 7 & 136.7 & 22.4 & 7 & 7 & 7 & 7 \\
\hline & May 2013 & 3 & 56.0 & 17.7 & 3 & 3 & 3 & 2 \\
\hline & Sep 2014 & 7 & 156.7 & 21.6 & 7 & 7 & 6 & 7 \\
\hline & Total & 29 & & & 29 & 29 & 28 & 28 \\
\hline \multirow[t]{5}{*}{ Symphodus melops } & May 2012 & 39 & 41.3 & 13.3 & 37 & 7 & 34 & 32 \\
\hline & Jun 2012 & 4 & 38.5 & 13,9 & 4 & 0 & 4 & 4 \\
\hline & Oct 2012 & 16 & 52.8 & 15.1 & 16 & 0 & 14 & 15 \\
\hline & May 2013 & 11 & 49.1 & 15.0 & 11 & 2 & 11 & 7 \\
\hline & Total & 70 & & & 68 & 9 & 63 & 58 \\
\hline
\end{tabular}

\section{PCR/real-time PCR}

RNA and DNA were extracted from individual gill samples (first gill arch) of all specimens from each species sampled (see Steigen et al. 2013), and RNA and DNA were stored at $-80^{\circ} \mathrm{C}$. The RNA used for real-time RT-PCR was quantified by Nanodrop, and the amounts used were always as recommended (around $600 \mathrm{ng}$ ) by the producer of the AgPath-ID ${ }^{\mathrm{TM}}$ One-Step kit (ThermoFisher Scientific). Real-time RTPCR was used for the detection of epitheliocystis agents belonging to the Cand. family Actinochlamydiaceae (Steigen et al. 2013), Ichthyobodo spp. (Isaksen et al. 2012), Paramoeba spp. (Table 2), VHSV (Duesund et al. 2010) and Paranucleospora theridion (syn.: Desmozoon lepeophtheirii) (Nylund et al. 2011). The assay for VHSV detects North Atlantic genotypes I, II and III.

The real-time assays published for the first time in this study were optimized as
Table 2. Taqman real-time RT-PCR assays used during the current study: Pspp (target: small subunit, SSU) for detection of Paramoeba spp; ChV (target: SSU) for detection of Candidatus Similichlamydia labri; ChW (target: SSU) for detection of a putative new species of Chlamydiae (family Candidatus Parilichlamydiaceae) present on the gills of wrasse. Elongation factor of the wrasse species (ElaUni; target: elongation factor) acts as an internal control for the quality of RNA extracted. The primers ElaUni-F and ElaUni-R can be used for all wrasse species except Symphodus melops (primers: ElaUni-Fsm and ElaUni-Rsm)

\begin{tabular}{|llc|}
\hline $\begin{array}{l}\text { Primer/ } \\
\text { probe }\end{array}$ & Sequence $\left(5^{\prime}-3^{\prime}\right)$ & $\begin{array}{c}\text { Assay } \\
\text { efficiency }\end{array}$ \\
\hline Pspp-F & TTG TCA GAG GTG AAA TTC TTG GAT T & \\
$\begin{array}{l}\text { Pspp-probe } \\
\text { Pspp-R }\end{array}$ & ATG AAA GAC GAA CTT CTG & 1.97 \\
ChV-F & GGG ACY CCG AGA GGR ACC TT & \\
ChV-probe & TRY GAG CGG CCT GTG & 1.96 \\
ChV-R & ARG CCA TTA CCY TAC CAA CAA GCT & \\
ChW-F & GGT GCT AAT ACC GAA TGT TGT TGA & \multirow{2}{*}{1.87} \\
ChW-probe & ATT TTC GAT GCC GAA & \\
ElaUni-F & GGA GTC CCC CGC TTT CAT & 1.87 \\
ElaUni-Fsm & CCC CTC CAG CAT GA GTC TAC AAA & \\
ElaUni-probe & ATY GGY GGT ATT GGA AC AC AAA & \\
ElaUni-Rsm & MAC ACG ACC GAC GGG TAC W & \\
ElaUni-R & AAC ACG RCC SAC GGG KAC W & \\
\hline
\end{tabular}


recommend for Taqman assays using different concentrations of primers and probes. Amplification efficiency $\left(E=\left[10^{1 /(- \text { slope })}\right]-1\right)$ was calculated for all new assays using a dilution series of RNA obtained from positive homogenate (Müller et al. 2002). Each dilution was tested in triplicate, and the average cycle threshold $(\mathrm{Ct})$ values were used to generate the standard curves. During real-time RT-PCR screening, the wrasse host house-keeping gene (elongation factor [ELF] assays; Table 2) was used as an internal control for the quality of the RNA extraction. New extractions of RNA from back-up tissues, followed by new real-time RT-PCR screening were carried out if initial results gave a $\mathrm{Ct}$ value $>20$ for ELF. It was not possible to use normalized expression to compare pathogen loads between the different wrasse species due to differences in the expression of ELF in gills of the different host species. Hence, we used Ct values (target: small subunit, SSU) as a relative measure of the amount of the wrasse Chlamydiae species. Nontemplate real-time PCR controls and non-template RNA-extraction controls for all assays were included in each real-time run.

DNA was used for sequencing of signature sequences from Ichthyobodo sp., Paranucleospora theridion and Paramoeba perurans. Sequencing of the partial SSU RNA gene of Ichthyobodo spp., Paramoeba spp. and $P$. theridion present on the gills of the wrasse species was performed from a selection of samples positive by real-time PCR, using primers published by Isaksen et al. (2012) and Nylund et al. (2008, 2010). The partial rRNA genes and the internal transcribed spacer (ITS) region of possible new Chlamydiae species were amplified by PCR and sequenced using degenerate primers targeting these regions in

Table 3. Primers used for PCR and sequencing of the 16S, ITS and 23S rDNA (partial) from Chlamydiae obtained from the gills of 5 different wrasse species. Primers 16sigF and 806R are general Chlamydiae primers; ChPL-F1, ChPL-R2 and ChPL-R3 target Cand. Similichlamydia labri; ChSL-F1, ChSL-R2 and ChSL-R3 target Clade A Chlamydiae; and Ch-ITS-F1 targets Cand. Actinochlamydia

\begin{tabular}{|llcl|}
\hline Primer & Sequence (5'-'3) & Target & Publication \\
\hline 16sigF & CGG CGT GGA TGA GGC AT & 16S & Draghi et al. (2004) \\
806R & GGA CTA CCA GGG TAT CTA AT & 16S & Draghi et al. (2004) \\
ChPL-F1 & GGT GCG TAG GCG GCT GAG & 16S & This study \\
ChSL-F1 & GGT GCG TAG GCG GCC ATA C & 16S & This study \\
Ch-ITS-F1 & GGA ATT GCT AGT AAT GGC G & 16S/ITS & Steigen et al. (2015) \\
ChPL-R2 & TGA TCT TAT TTT ACG GAT CAG & ITS & This study \\
ChSL-R2 & TCT TTT CAT CTT TAA AAG AGT C & ITS & This study \\
ChPL-R3 & AGG ATA CCA ACT TGT GCT TTC & 23S & This study \\
ChSL-R3 & GAT ACC AAC TAA GAA AAC CC & 23S & This study \\
\hline
\end{tabular}

members of Chlamydiales and Cand. families Actinochlamydiaceae and Parilichlamydiaceae (Table 3). Amplified PCR products were sequenced from a selection of wrasse species, positive by RT-PCR. Two putative new species of Chlamydiae were detected, and the sequences were deposited in GenBank. A real-time RT PCR assay (ChW) (Table 2) was developed based on the 16S rRNA gene sequence of 1 of the putative new species. This assay did not amplify Cand. S. labri and gave a positive result only when the putative new Chlamydiae species was present (Table 1).

\section{Phylogeny of Chlamydiae species identified from wrasse}

Preliminary species identification using sequence data from Chlamydiae-positive samples was performed by searching the public GenBank database for homologous sequences using BLAST (2.0). The Vector NTI Suite software package was used to generate multiple alignments with related sequences. Selected sequences from all existing families of the order Chlamydiales, available on the EMBL nucleotide database, were also included in pairwise sequence comparisons (from Oreochromis niloticus, Serranus scriba and Cyclopterus lumpus). The multiple sequence alignment editor GeneDoc (available at http://genedoc.software.informer.com) was used for manual adjustment of the sequence alignments (gaps in the alignments were removed). The best-fit nucleotide substitution model for the dataset was GTR+I+G identified by Modeltest 3.6 (Posada \& Crandall 1998), and this was implemented in the analysis. The maximum likelihood tree was generated and bootstrapped (50000 puzzling steps) in TREE_PUZZLE 5.2 (current version, available at www. tree-puzzle.de). Phylogenetic trees were drawn using TreeView (Page 1996).

\section{RESULTS}

All wrasse specimens collected were taken alive to the laboratory. The fish looked healthy except for slight scratches on fins and skin related to netting. The identification of the wrasse species was based on morphology and was confirmed by se- 
quencing of the mitochondrial cox1 gene (448 nt from 46 individual sequences). We did not find any within-species variation in cox1 gene sequences used for the bar coding, confirming our morphological determination of the species. A phylogenetic tree showing relationships between the wrasse species is shown in Fig. S1 of the Supplement at www.int-res. com/articles/suppl/d128p021_supp.pdf.

\section{Real-time PCR assays}

Ct values obtained for the ELF were relatively stable within the gills of the individual wrasse species, but were different between species. The mean $\mathrm{Ct}$ values obtained from the gills of Labrus mixtus, $L$. bergylta, Ctenolabrus rupestris, Centrolabrus exoletus and Symphodus melops were 14.0, 15.3, 19.0, 19.1 and 17.0 , respectively.

\section{Parasites and VHSV}

Crustacean parasites were observed both on the skin (Caligus centrodonti) and gills (Hatschekia sp.) of L. bergylta only. Gill pathology (hyperplasia and necrosis) was observed at the attachment sites for the latter.

Trichodinids were relatively abundant on histological sections of gills from Ctenolabrus rupestris, $L$. mixtus and $S$. melops, but no pathology was associated with their presence (Fig. 1).

Ichthyobodo spp. showed close to $100 \%$ prevalence (real-time RT-PCR screening) on all 5 wrasse species (Table 1). Partial 18S rDNA sequences of Ichthyobodo sp. (accession nos. KF179521-KF179526), obtained from the gills of L. mixtus $(\mathrm{n}=2)$, L. bergylta $(\mathrm{n}=3)$ and $S$. melops $(\mathrm{n}=1)$, could represent a putative new species within this genus. The partial 18S sequences (1745 nt) of the Ichthyobodo sp. from these wrasse showed 96.6, 97.0 and $95.0 \%$ identity to $I$. salmonis (Norway), Ichthyobodo sp. from Oncorhynchus masou (Japan) and Ichthyobodo sp. from Gadus morhua (Norway), respectively. The SSU gene from Ichthyobodo spp. from the gills of $C$. exoletus and $C$. rupestris was not sequenced. The density of these Ichthyobodo spp., based on real-time RT-PCR data, was low, and no gill pathology connected to this parasite was observed.

Light microscopy detected the presence of Paramoeba spp. on the gills of some specimens (Fig. 2A,B). This was confirmed by real-time RT-PCR on the gills of 17 individuals of 47 tested $L$. bergylta and on 5 of 22 tested $L$. mixtus. The other 3 wrasse species (C. rupestris $[\mathrm{n}=25]$, C. exoletus $[\mathrm{n}=$ 16] and $S$. melops [n = 31]) were all negative for the presence of Paramoeba spp.; $P$. perurans was identified by sequencing (accession no. KF179520) on the gill of L. bergylta
Fig. 1. (A) Presence of trichodinids (arrows) on the gills of Ctenolabrus rupestris. Scale bar $=100 \mu \mathrm{m}$. (B) Magnification of the trichodinid (arrow). Scale bar $=20 \mu \mathrm{m}$. (C) Trichodina sp. (arrow) on the gills of Symphodus melops. Scale bar $=20 \mu \mathrm{m}$ 
only. No gill pathology was observed in the tissue sections from the gills of $L$. bergylta or L. mixtus despite the presence of Paramoeba spp.

The microsporidian Paranucleospora theridion (syn.: Desmozoon lepeophtheirii) was detected in the gills of nearly all host individuals, with the lowest prevalence $(71.4 \%)$ on the gills of $L$. bergylta. The SSU (rRNA) of $P$. theridion was sequenced from parasites in the gills of $C$. exoletus (accession no. KR187183) and L. mixtus (KR187184，KR187185; Table 1). The densities of this parasite were low on the gills of all wrasse species, based on the obtained real-time RT-PCR values $(\mathrm{Ct}>21)$ (Nylund et al. 2011). Spores of the parasites could not be observed in the tissue sections of the gills ( $\mathrm{n}=3$ fish species $^{-1}$ ).

Histological examination of gills from a selection of the collected wrasse species $\left(\mathrm{n}=3\right.$ fish species $^{-1}$ ) showed that a single individual of $L$. bergylta was positive for the presence of a xenomaforming microsporidian (Fig. 2C,D). Hyperplasia was seen in areas with xenoma.

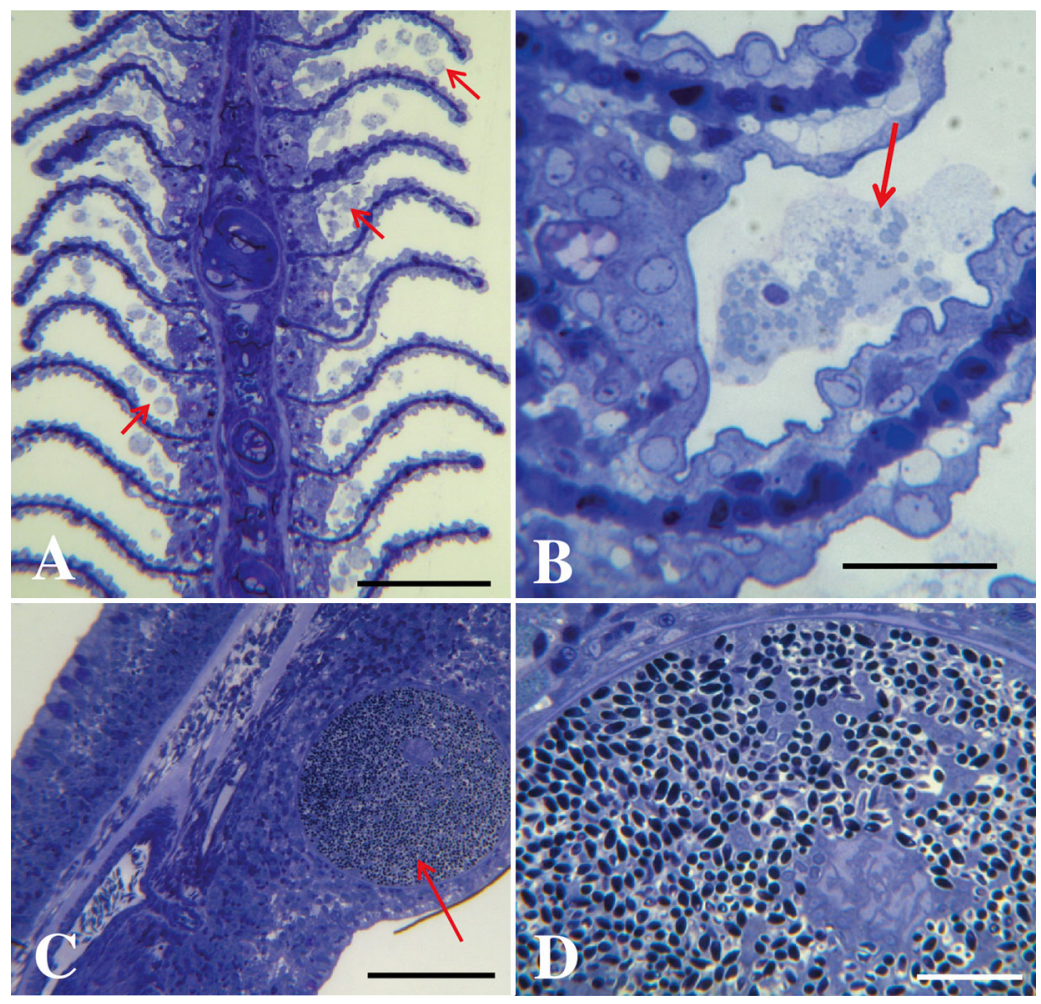

Fig. 2. (A) Paramoeba perurans (arrows) on the gills of Labrus bergylta. Scale bar $=100 \mu \mathrm{m}$. (B) Magnification of $P$. perurans (arrow). Scale bar $=20 \mu \mathrm{m}$. (C) Xenoma-forming microsporidian (arrow) on the gills of $L$. bergylta. Scale bar $=100 \mu \mathrm{m}$. (D) Magnification of the xenoma showing presence of microspores. Scale bar $=20 \mu \mathrm{m}$

All wrasse species were tested individually (real-time RT-PCR) for presence of VHSV and were found to be negative (Table 1).

\section{Gill Chlamydiae}

Screening of gill tissues (real-time RT-PCR) from all 5 wrasse species with respect to presence of members of the Cand. family Actinochlamydiaceae showed close to $100 \%$ prevalence in all species (Table 1). Only 2 specimens of $S$. melops, collected on 23 May 2012, were negative for this group of bacteria (i.e. prevalence $=97.1 \%$ ). The 2 Labrus species carried the highest amount of Actinochlamydiaceae based on comparative real-time RT-PCR results (and standardised amount of RNA analysed per sample; Fig. 3). One group of Chlamydiae 16S rRNA gene sequences (1464 nt) obtained from all 5 wrasse species showed $>98.9 \%$ identity to Cand. Similichlamydia labri, $97.0 \%$ identity to Cand. S. latridicola, 97.5\% identity to Cand. S. laticola and $95.0 \%$ identity to Cand. Actinochlamydia clariae (Table 4). The second group of wrasse Chlamydiae (referred to as

Clade A), showed a high prevalence (92.1-100.0\%) and load (Ct values $<20$ ) on the gills of $L$. bergylta, $L$. mixtus and C. rupestris, a low prevalence on $S$. melops $(12.9 \%)$ and were absent from the gill of $C$. exoletus (Table 1, Fig. 3). Members of Clade A showed 96.6 to $96.8 \%$ identity to Cand. Parilichlamydia carangidicola based on $1103 \mathrm{nt}$ from the 16S rRNA gene. The 16S sequence identity of members of Clade A to the Cand. species A. clariae, S. labri and Piscichlamydia salmonis were 93.0, 93.9 and $86.7 \%$, respectively (Table 4 ). One specimen of $S$. melops was also positive for a possible new member of the Chlamydiales family Simkaniaceae (accession no. KC608868; Fig. 4).

The partial 16S gene from members of Cand. S. labri or closely related to this species was sequenced from 26 of the wrasse specimens with 3 or more sequence isolates from each wrasse species, while 11 sequences of the $16 \mathrm{~S}$ gene were obtained from wrasse carrying members of Clade A (see Figs. 4 $\& 5)$. These sequences were used in a phylogenetic analysis, which included members from each of the families in the order Chlamydiales (Fig. 4). The phy- 


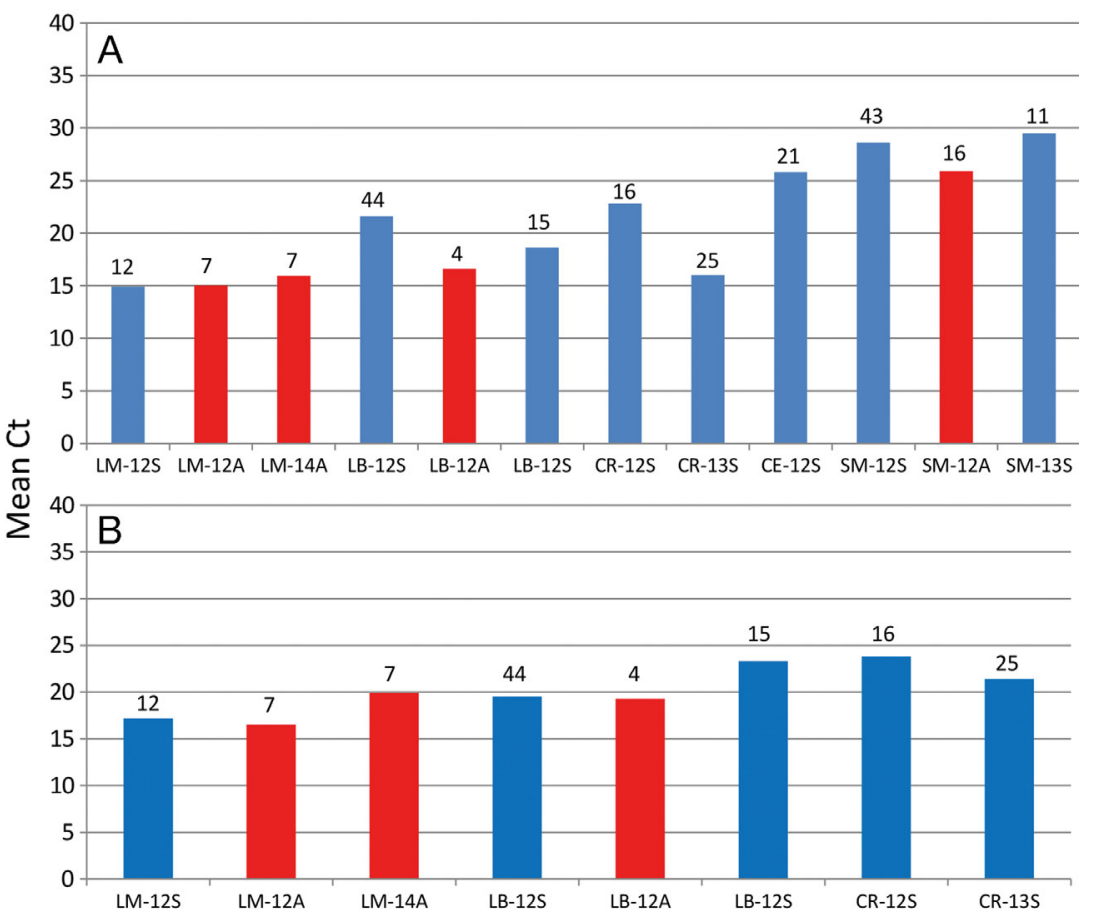

Fig. 3. Mean Ct values resulting from real-time RT-PCR analysis of gills from the wrasse species with respect to presence of Chlamydiae showing 16S rDNA sequence similarity to (A) Candidatus Similichlamydia labri and (B) Clade A Chlamydiae. LM: Labrus mixtus; LB: L. bergylta; CR: Ctenolabrus rupestris; CE: Centrolabrus exoletus; SM: Symphodus melops. Collection times were 12S: spring/summer 2012; 13S: spring/summer 2013; 12A: autumn 2012; 13A: autumn $2013 ;$ 14A: autumn 2014 . The number at the top of each column represents number of fish. Blue columns: spring/summer catch; red columns: autumn catch

logeny showed that the majority of Chlamydiae $16 \mathrm{~S}$ sequences isolated from the different wrasse species grouped into a distinct clade together with Cand. S. labri, while the other 16S rRNA gene sequences $(\mathrm{n}=$ 11) constituted a distinct clade with the closest affinity to Cand. P. carangidicola.

Six additional sequences obtained from the gills of Oreochromis niloticus (accession nos. JQ480302, JQ480303, KT158464), Serranus scriba (KF805948) and Cyclopterus lumpus (KF805949, KF805950) also belonged to this major branch in the phylogeny, which consisted of 2 Cand. families, Actinochlamydiaceae and Parilichlamydiaceae (Fig. 4). The Cand. S. labri-like sequences and the Clade A sequences grouped within the former and latter families, respectively. This branch in the order Chlamydiales contained 16S rRNA sequences from the gills of both fresh- and seawater fishes.

The ITS region (177 nucleotides) and the first $400 \mathrm{nt}$ of the 23S rRNA gene were sequenced from the Chlamydiae present on the gills from all 5 wrasse species, from C. lumpus, S. scriba, O. niloticus and from Cand. A. clariae from African catfish. The partial 16S rRNA gene (1502 nt), the ITS (177 nt) and the partial 23S rRNA gene (396 nt) were used in a second phylogenetic analyses of the Chlamydiae from the wrasse species (Fig. 5). Using all of the above gene regions (2102 nt) did not change the relationship between the wrasse Chlamydiae, but gave a slightly better separation of the wrasse Chlamydiae and the Chlamydiae from other fish species (cf. Figs. 4 \& 5).

Clade A was distinct for all sequences. To clarify this, alignments of Cand. S. labri and Clade A from the wrasse species are shown in Fig. S2 of the Supplement.

\section{Inclusion morphology in L. mixtus}

Epitheliocysts from L. mixtus were mostly located basally between the secondary gill lamellae. The largest size of the cysts measured was about $120 \mu \mathrm{m}$, and the shape of the cysts varied from round/oval to irregular (Fig. 6). A high number of actinae (more than 200 were counted on 1 section through an inclusion) radiated from the inclusion membrane. On semi sections, the inclusion filled nearly the whole host cell in large cysts, while the smaller inclusions were surrounded by a lighter stained area.

Studies of the ultrastructure of the larger epitheliocysts showed that the inclusion membrane was associated with a thick layer (ca. 35-100 nm thick, thicker near the base of the actinae) of electron-dense material (probably proteins) that was also present in the actinae (Figs. $7 \&$ \&). Actinae extending from the inclusion membrane were highly abundant, very irregular in transverse sections and seemed to be branching. Abundant mitochondria and amorphous material were located between the actinae. In the smaller cysts, the actinae seemed to end before they reached the host cell surface. The volume from the end of the actinae to the cell membrane in these host cells was packed with endoplasmic reticulum and mitochondria. The endoplasmic reticulum seemed to contain material with the same electron density as that found in the actinae. Bundles of filaments (prob- 
Table 4. Sequence similarity (\%) of the partial Chlamydiae 16S rRNA gene obtained from gills of different fish species: Clade A from wrasse in the current study (1465 nt, accession no. KC469554), Cand. Similichlamydia labri (1464 nt, KC469556), Cand. S. latridicola (1396 nt, JQ687061) from Latris lineata, Cand. S. laticola (1402 nt, KF219613) from Lates calcarifer, Cand. Actinochlamydia clariae (1464 nt, JQ480300) from Clarias gariepinus, Cand. P. carangidicola (1103 nt, JQ673516) from Seriola lalandi and Cand. P. salmonis from Salmo salar (1470 nt, AY462244). Chlamydiae sequences obtained from the gills of Oreochromis niloticus, Cyclopterus lumpus and Serranus scriba are also included

\begin{tabular}{|c|c|c|c|c|c|c|c|}
\hline Host/seq. ID & Clade A & $\begin{array}{l}\text { Cand. } \\
\text { S. labri }\end{array}$ & $\begin{array}{c}\text { Cand. } \\
\text { S. latridicola }\end{array}$ & $\begin{array}{l}\text { Cand. } \\
\text { S. laticola }\end{array}$ & $\begin{array}{l}\text { Cand. } \\
\text { A. clariae }\end{array}$ & $\begin{array}{c}\text { Cand. } \\
\text { P. carangidicola }\end{array}$ & $\begin{array}{c}\text { Cand. } \\
\text { P. salmonis }\end{array}$ \\
\hline \multicolumn{8}{|c|}{ Labrus bergylta } \\
\hline KC469561 & 100.0 & 93.9 & 93.7 & 93.7 & 93.0 & 96.8 & 86.7 \\
\hline KC469554 & 100.0 & 93.9 & 93.7 & 93.7 & 93.0 & 96.8 & 86.7 \\
\hline KC469555 & 100.0 & 93.9 & 93.7 & 93.7 & 93.0 & 96.8 & 86.7 \\
\hline KC469563 & 100.0 & 93.9 & 93.7 & 93.7 & 93.0 & 96.8 & 86.7 \\
\hline KC469559 & 100.0 & 93.9 & 93.7 & 93.7 & 93.0 & 96.8 & 86.7 \\
\hline KC469560 & 100.0 & 93.9 & 93.7 & 93.7 & 93.0 & 96.8 & 86.7 \\
\hline KT030895 & 99.9 & 93.9 & 93.8 & 93.2 & 92.9 & 96.8 & 86.8 \\
\hline КT030892 & 100.0 & 93.9 & 93.7 & 93.7 & 93.0 & 96.8 & 86.7 \\
\hline KT030894 & 93.2 & 99.3 & 97.2 & 97.4 & 94.6 & 93.1 & 86.8 \\
\hline \multicolumn{8}{|l|}{ L. mixtus } \\
\hline KT030898 & 99.9 & 93.8 & 93.6 & 93.7 & 92.9 & 96.6 & 86.8 \\
\hline KT030896 & 100.0 & 93.6 & 93.7 & 93.8 & 92.9 & 96.8 & 86.8 \\
\hline KC469545 & 93.7 & 99.7 & 97.2 & 97.6 & 94.9 & 93.5 & 86.7 \\
\hline KC469565 & 93.7 & 99.7 & 97.2 & 97.5 & 94.9 & 93.5 & 86.7 \\
\hline KC469566 & 93.7 & 99.7 & 97.2 & 97.6 & 94.9 & 93.5 & 86.7 \\
\hline \multicolumn{8}{|c|}{ Centrolabrus exoletus } \\
\hline KC469549 & 93.9 & 99.0 & 97.1 & 97.6 & 95.5 & 92.9 & 86.6 \\
\hline \multicolumn{8}{|c|}{ Ctenolabrus rupestris } \\
\hline KT158463 & 99.5 & 93.6 & 93.3 & 93.5 & 92.7 & 96.6 & 86.5 \\
\hline KC469551 & 93.7 & 99.0 & 97.0 & 97.6 & 94.5 & 93.2 & 86.4 \\
\hline KC469552 & 93.9 & 98.9 & 97.0 & 97.4 & 94.5 & 93.0 & 86.4 \\
\hline \multicolumn{8}{|c|}{ Symphodus melops } \\
\hline KC469568 & 94.0 & 99.1 & 97.3 & 97.6 & 94.7 & 93.1 & 86.6 \\
\hline \multicolumn{8}{|c|}{ Cyclopterus lumpus } \\
\hline KF805949 & 94.2 & 97.7 & 97.6 & 97.5 & 95.2 & 93.8 & 86.8 \\
\hline \multicolumn{8}{|c|}{ Serranus scriba } \\
\hline KF805948 & 94.8 & 96.3 & 96.4 & 96.4 & 94.3 & 93.8 & 86.5 \\
\hline \multicolumn{8}{|c|}{ Oreochromis niloticus } \\
\hline KT158464 ${ }^{\mathrm{a}}$ & 93.0 & 95.1 & 95.1 & 94.6 & 94.6 & 92.6 & 86.7 \\
\hline JQ480303 & 93.2 & 95.3 & 95.5 & 95.1 & 94.8 & 93.0 & 86.4 \\
\hline
\end{tabular}

ably actin) were also present in the host cell cytoplasm (Fig. 8C). Chloride cells, in contact with infected host cells, seemed to lose their cell membrane in the contact area, which suggested that they are incorporated as a part of (merged with) the infected cell. The chloride cells on the gill of L. mixtus contained high amounts of mitochondria.

The gill inclusions in L. mixtus were filled with highly polymorphic bacteria that varied from coccoid shapes to larger irregularly shaped morphs. The bacteria were surrounded by electron-dense amorphous material. Despite the variation in the morphology of the bacteria inside the inclusions, their cytoplasm seemed to be very similar, consisting of amorphous material with a slightly higher electron density towards the surrounding bacterial cell membrane. When containing the central part of the nucleoid, the smaller coccoid morphs measured 0.5-0.7 $\mu \mathrm{m}$ in mean diameter. They were all smaller than what has been termed reticulate body-like morphs in the cysts found in Clarias gariepinus (Steigen et al. 2013). 


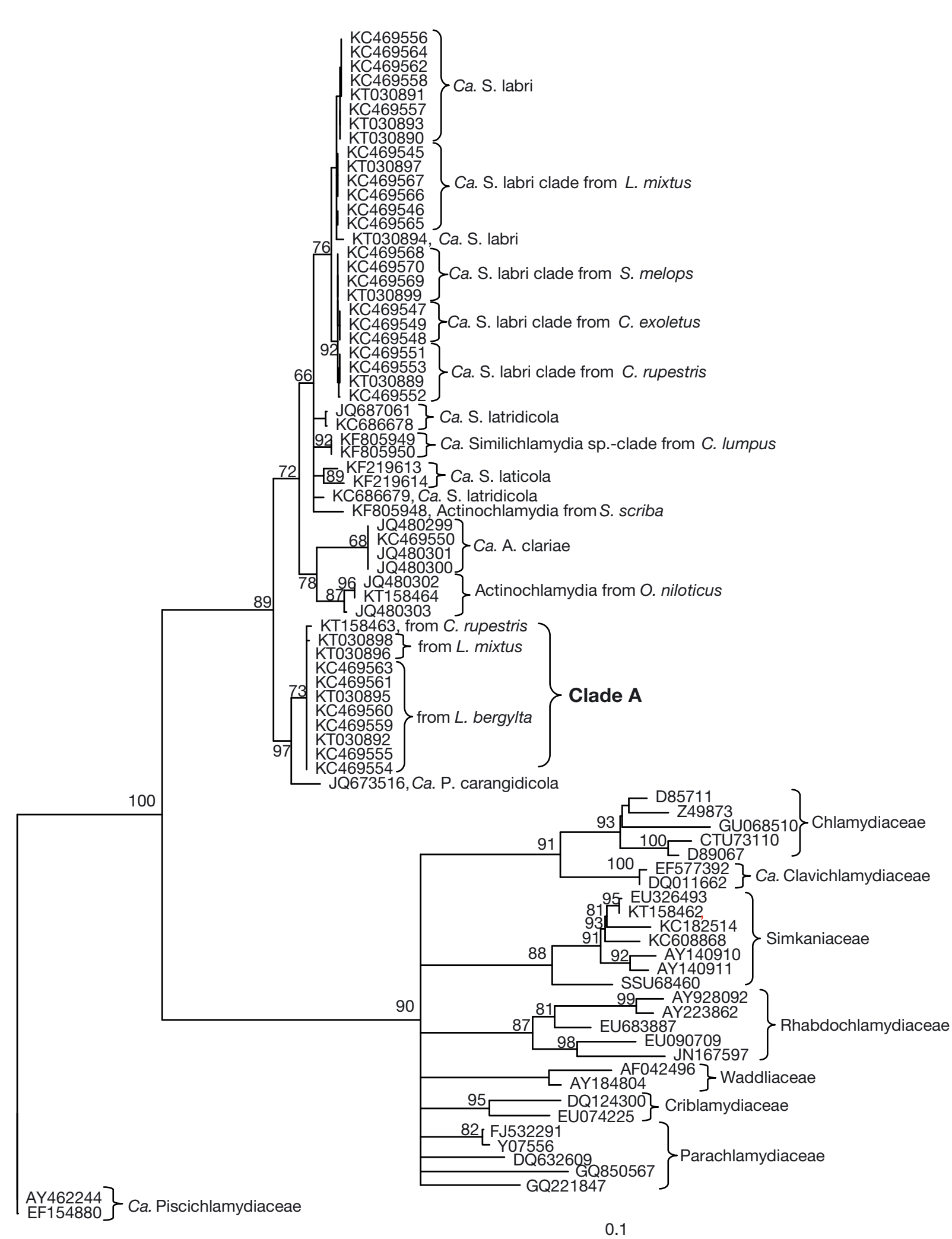

Fig. 4. Phylogenetic tree showing the relationships between the wrasse Chlamydiae and other members of Chlamydiales based on 16S rDNA only. Cand. Piscichlamydia salmonis is used as the outgroup. The analysis is based on 1103 nt from the 16S rRNA gene excluding parts of the loops. The scale bar shows the number of nucleotide substitutions as a proportion of branch length 


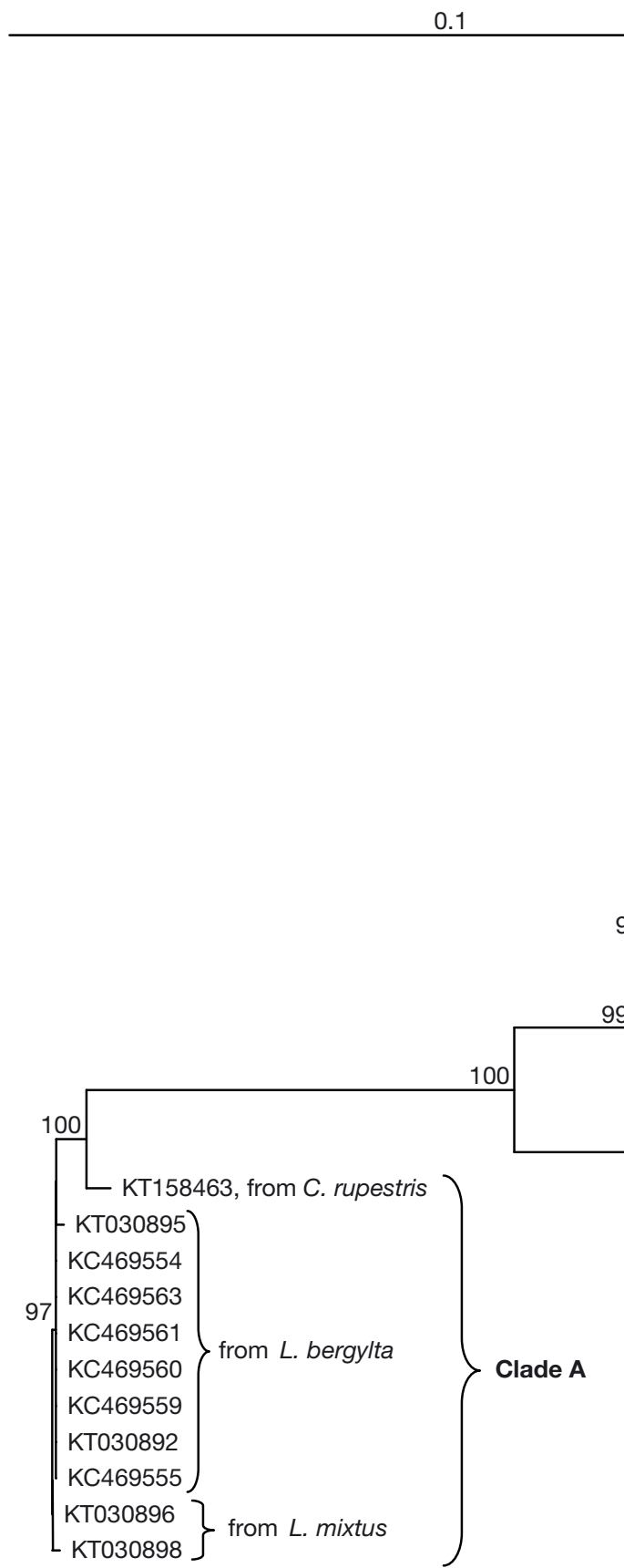

DISCUSSION

This study includes only a limited number of possible pathogens that could be present on the gills of wrasse in Norway. Trichodinids are not considered as parasites, but may constitute a problem in rearing tanks with high densities of wrasse (A. Nylund pers. obs.). Trichodinids occurred at high abundance on the gills of some individuals of the wild-caught wrasse used in this study, but no pathology was associated with the presence of these ciliates.

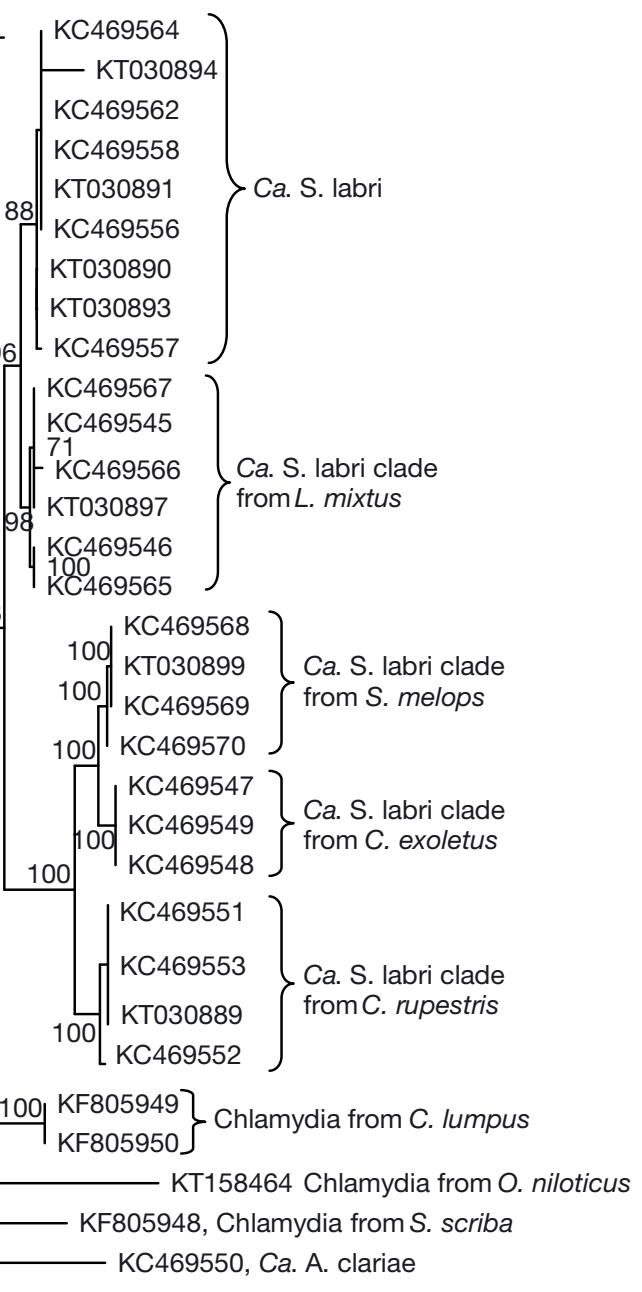

469550, Ca. A. clariae
Fig. 5. Phylogenetic tree showing the relationships between the wrasse Chlamydiae, Candidatus A. clariae and Chlamydiae from Cyclopterus lumpus, Serranus scriba and Oreochromis niloticus based on an alignment using the 16S rRNA gene, the internal transcribed spacer (ITS) region and the partial 23S rRNA gene (2102 nt)

The prevalence of Ichthyobodo spp. was very high on the gills of all 5 wrasse species, but their importance as pathogens is not addressed in this study. Ichthyobodo spp. have been associated with serious diseases in other fish species (Isaksen 2013) and could be of importance in dense populations of wrasse in culture facilities and in salmon cages. However, in this study, no gill lesions were observed in connection with the presence of Ichthyobodo spp. on the wrasse gills. The Ichthyobodo sp. from 3 wrasse species, based on the rRNA gene, represents a puta- 


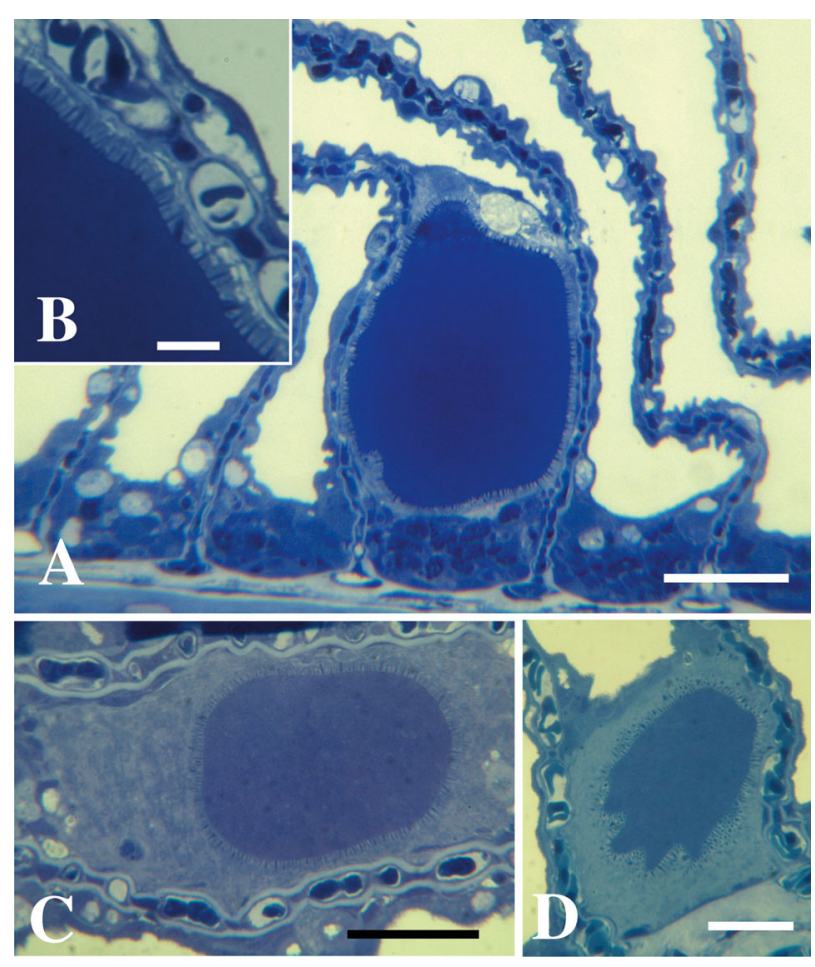

Fig. 6. Epitheliocystis on the gills of Labrus mixtus. (A) Large cyst located basal to the secondary lamellae. Actinia are radiating from the inclusion. No visible response can be seen in the surrounding tissue. Scale bar $=40.0 \mu \mathrm{m}$. (B) Magnification of the actinia radiating from the inclusion wall. Scale bar $=20$ $\mu \mathrm{m}(\mathrm{C})$ Inclusion with a high number of radiating actiniae (about 200) surrounded by a large pale-staining area. Scale bar $=25.0 \mu \mathrm{m}$. (D) Asymmetric inclusion. Scale bar $=20 \mu \mathrm{m}$

tive new and different species compared to the 2 species described from Atlantic salmon (Isaksen et al. 2010, 2011). Hence, use of wrasse as cleaner fish in salmon farms may not represent a risk of introduction and transmission of this parasite to the salmon population. Nothing is known about the prevalence of this putative new species of Ichthyobodo in other wild populations of wrasse along the Norwegian coast.

Paramoeba perurans has already been associated with mortalities in culture facilities of Labrus bergylta (Karlsbakk et al. 2013) and is also recognized as a serious pathogen in salmon farms worldwide (Young et al. 2008, Crosbie et al. 2012). However, we did not observe any pathology on the gills of the 2 Labrus spp. from which the SSU rDNA sequence of $P$. perurans was obtained. Experimental studies will have to be performed to determine if wrasse can be important for the introduction to and transmission of $P$. perurans in salmon farms. The geographical distribution of $P$. perurans in Norwegian wrasse populations is not known.

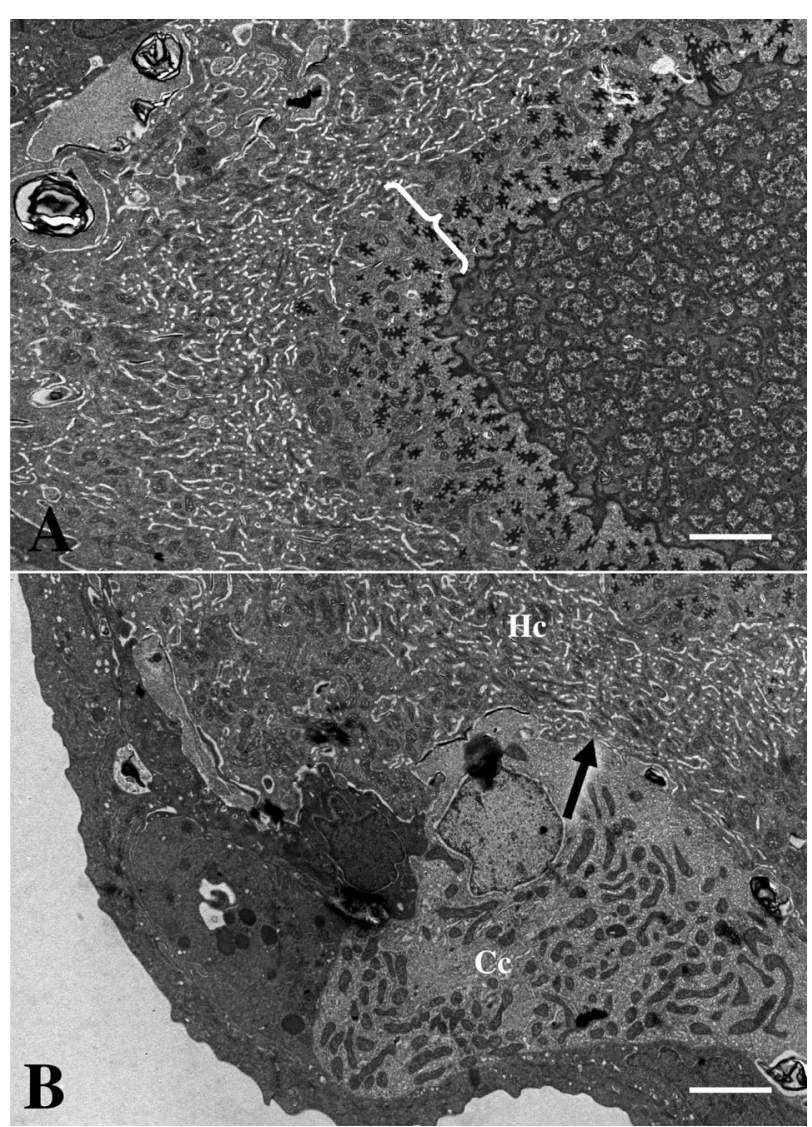

Fig. 7. Epitheliocysts in Labrus mixtus. (A) Inclusion containing pleomorphic bacteria. A high number of actinae extend from the inclusion membrane and into the host cell cytoplasm. The cytosol closest to the inclusion, between the actinae, contains mitochondria and amorphic material, while the cytosol peripheral to the inclusion contains high amounts of endoplasmic reticulum and mitochondria (bracket). Scale bar $=2.0 \mu \mathrm{m}$. (B) Chloride cell $(\mathrm{Cc})$ containing a large amount of mitochondria, associated with a host cell (Hc) containing an inclusion. Part of the cell membrane is lost between the infected cell and the chloride cell (arrow). Scale bar $=2.0 \mu \mathrm{m}$

The xenoma-forming microsporidian is possibly a Loma species (cf. Askeland 2002), and other members of this genus are associated with disease and mortality (Kent et al. 1989, Brown et al. 2010); however, there are no reports of diseases in wrasse associated with this parasite in Norway.

The abundance of the copepod parasite Hatschekia sp. was relatively low on the examined individuals, and the only changes in the infected hosts were at the attachment sites of the parasite.

VHSV was not detected in any of the wrasse species even though this virus has been detected in other wild fish species along the Norwegian coast and in wrasse in salmon farms in Shetland, Scotland 


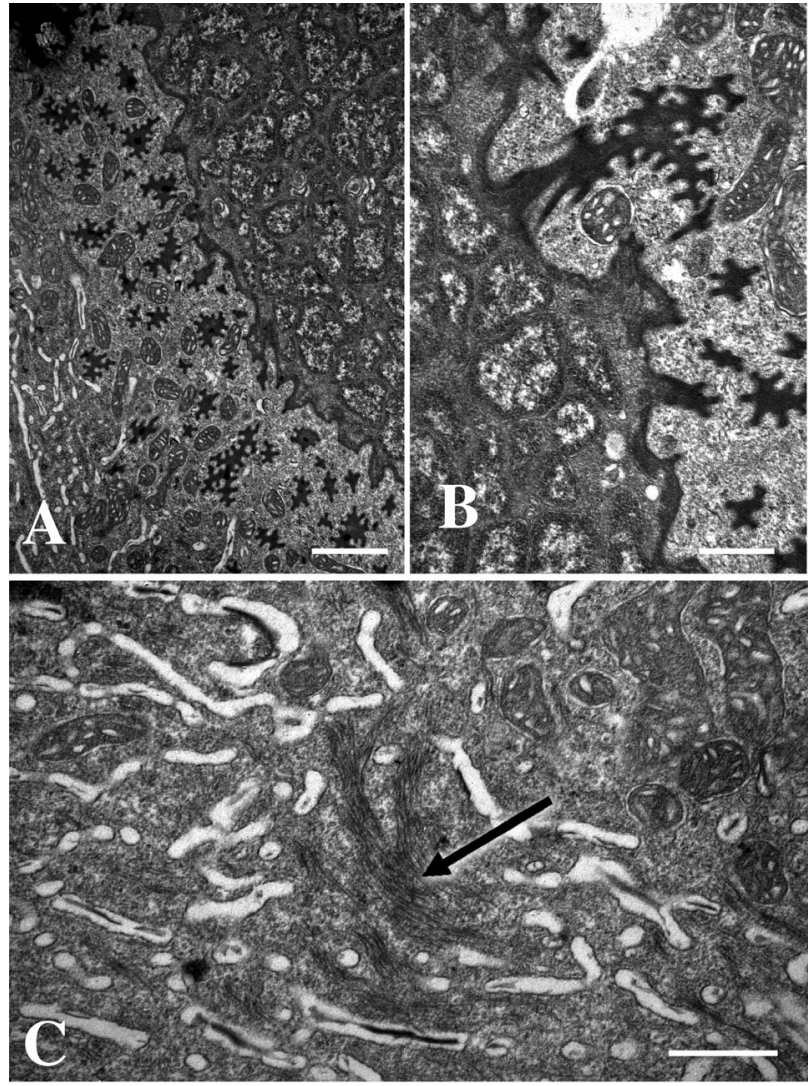

Fig. 8. Epitheliocysts in Labrus mixtus. (A) Transverse section of several irregularly shaped actinae radiating from the inclusion membrane. Scale bar $=1.0 \mu \mathrm{m}$. (B) The actinae seem to be branching in the host cell cytosol. Scale bar $=0.5$ $\mu \mathrm{m}$. (C) Large amounts of filaments (arrow) accumulating in some of the infected host cells in the area consisting of endoplasmic reticulum and mitochondria. Scale bar $=0.5 \mu \mathrm{m}$

(Duesund et al. 2010, Johansen et al. 2013, Sandlund et al. 2014, Munro et al. 2015, Wallace et al. 2015). The wrasse in Shetland were infected with VHSV genotype III, while only genotype I has been detected in wild fish along the Norwegian coast (Duesund et al. 2010, Johansen et al. 2013, Sandlund et al. 2014, Wallace et al. 2015). VHSV genotype III was detected in a few seawater rainbow trout farms in western Norway in the period 2007-2008, but it has not been possible to identify the source of the virus in these farms (Duesund et al. 2010). Genotype III seems to have a natural distribution in the Skagerrak, the North Sea and around the British Isles (Einer-Jensen et al. 2004, Snow et al. 2004, Wallace et al. 2015).

The number of available 16S rRNA sequences from bacteria has increased rapidly during the last decade. These signature sequences are always included in the description of new species of bacteria, i.e. every spe- cies description contains a phylogenetic analysis of the type strain based on 16S rRNA gene sequence even though high conservation of rRNA reduces its discrimination power and may not separate between closely related species. DNA-DNA hybridization is considered the 'gold standard' for species delimitation, but due to the workload involved it was suggested that such experiments need only be performed for isolates that share 16S rRNA gene sequence similarities above $97 \%$ (Stackebrandt \& Goebel 1994). However, based on experience, this recommendation was changed in 2006. It was suggested that a $16 \mathrm{~S}$ rRNA gene sequence similarity threshold range of 98.7-99.0\% should be set as a level before DNA-DNA reassociation experiments are necessary (Stackebrandt \& Ebers 2006). In a later study, based on the genomes of 6787 prokaryotes belonging to 22 phyla, it was shown that $98.65 \%$ 16S rRNA gene sequence similarity can be used as a threshold for separating species (Kim et al. 2014). This suggested change in threshold for species differentiation will have implications for description of bacteria that are not cultivable at present, and therefore mostly excludes DNA-DNA reassociation experiments and many phenotypic tests.

All members of Chlamydiae detected on the gills of different fish species, including those from the wrasse species, cannot be cultivated, which means that the species descriptions must be based on $16 \mathrm{~S}$ rRNA gene sequences and core genes (such as housekeeping genes), inclusions, bacterial morphology and host species (Greub 2013). The characterized Candidatus species within Chlamydiales obtained from fish are Cand. Piscichlamydia salmonis, Cand. Clavichlamydia salmonicola, Cand. Actinochlamydia clariae, Cand. Parilichlamydia carangidicola, Cand. Renichlamydia lutjani, Cand. Syngnamydia venezia, Cand. Syngnamydia salmonis, Cand. Similichlamydia latridicola, Cand. Similichlamydia laticola and Cand. Similichlamydia labri (Draghi et al. 2004, Karlsen et al. 2008, Corsaro \& Work 2012, Fehr et al. 2013, Steigen et al. 2013, 2015, Stride et al. 2013a,b,c, Nylund et al. 2015). In addition to these Candidatus species, there is a large number of Chlamydiae-related 16S rRNA gene sequences available that have been obtained from fish suffering from epitheliocystis. This suggests a high diversity and presence of a wide range of new species within Chlamydiales associated with fish (Meijer et al. 2006, Draghi et al. 2007, Polkinghorne et al. 2010, Corsaro \& Work 2012, Camus et al. 2013, Lai et al. 2013, Nylund et al. 2015).

The 16S rRNA gene sequences of 1 group of gill Chlamydiae from Ctenolabrus rupestris, Symphodus 
melops, Centrolabrus exoletus and Labrus mixtus show $>98.9 \%$ similarity to Cand. S. labri described from L. bergylta in western Norway (Steigen et al. 2015). A strict interpretation of the criteria for separation of Chlamydiae species based on 16S rDNA suggests that these bacteria, from the different wrasse species, belong to the species Cand. S. labri described from L. bergylta (cf. Everett et al. 1999, Bush \& Everett 2001, Kim et al. 2014, Steigen et al. 2015). However, when the phylogenetic analysis is expanded to include the ITS and partial 23S regions in addition to the $16 \mathrm{~S}$, they are separated into distinct and well supported clades reflecting the host species. If future research, including other Chlamydiae gene sequences, should show that Chlamydiae from the different wrasse species are distinct species then the use of 16S rRNA gene sequences for demarcation or separation of intracellular bacteria like Chlamydiae will have to be reconsidered (cf. Stackebrandt 2009).

The other group of Chlamydiae obtained from $L$. bergylta and L. mixtus, Clade A (Figs. 5 \& 6) represent a putative new species in the Cand. genus Parilichlamydia. The closest relative to Clade A is Cand. P. carangidicola (accession no. JQ673516) from Australian waters. Other putative new species of Chlamydiae, based on 16S rRNA gene sequences only, are present on the gills of Oreochromis niloticus, collected in and around Lake Victoria, Serranus scriba from the Mediterranean Sea and Cyclopterus lumpus from western Norway. This shows the wide geographical distribution of these closely related Chlamydiae.

It is worth noting that the overall phylogeny of wrasse (Figs. S1 \& S2) fits with the phylogeny of the putative Chlamydiae species and Clade A, indicating host-species specificity of the Chlamydiae.

Gill-associated Chlamydiae occurred at high prevalence in all 5 wrasse species from the west coast of Norway. However, this paper describes the morphology of cysts, inclusions and associated bacteria from the gills of $L$. mixtus only. We did not observe cysts on the gills of $C$. rupestris, $C$. exoletus and $S$. melops, which could be due to a relative low density of bacteria in these wrasse species (inferred from RT-PCR Ct values). The cysts and the inclusions on the gills of $L$. mixtus showed similarities to that of Cand. Similichlamydia labri from L. bergylta and Cand. A. clariae described from the gills of Clarias gariepinus in Uganda (Steigen et al. 2013, 2015). However, the inclusions and the epitheliocysts were larger in L. mixtus, reaching $120 \mu \mathrm{m}$ in diameter, compared to that observed in L. bergylta and C. gariepinus. They all share actiniae radiating from the inclusion, but the number of actiniae was much higher in epitheliocysts from L. mixtus. Large cysts were also described on the gills of Latris lineata and Lates calcarifer infected with Cand. S. latridicola and Cand. S. laticola, respectively (cf. Stride et al. 2013b,c), but actiniae cannot be seen on any of the pictures included, and the ultrastructure/morphology of the bacteria inside the inclusions was not presented. A comparison of the bacteria within the cysts of L. mixtus, described in the current study, with these 2 Candidatus species can only be based on the partial 16S rDNA. This is of course assuming that the Chlamydiae sequences obtained here from infected $L$. mixtus represented those bacteria observed in cysts in this host, as an in situ hybridization assay was not used to confirm the link.

Steigen et al. (2013) discussed the possible function of the actiniae radiating from the inclusion membrane in Actinochlamydiaceae. It was suggested that they may have a function both in the uptake of nutrients for the growing bacteria inside the inclusion and for the expansion of the growth environment for these intracellular bacteria. The actiniae radiating from the inclusions in C. gariepinus are seen penetrating the cell membrane of neighbouring cells (Steigen et al. 2013), while this is less obvious in the L. mixtus inclusions presented here. However, the cell membranes of neighbouring chloride cells to the epitheliocysts in L. mixtus seemed to fuse with the cell membranes of the infected host cells. This resulted in large host cells containing abundant amounts of mitochondria and endoplasmic reticulum and may explain why the epitheliocysts were enlarged to $120 \mu \mathrm{m}$ in diameter in this host species. Inclusion of neighbouring cells as part of the epitheliocysts, a sort of syncytium formation, has not been observed in other members of Chlamydiae outside the Cand. family Actinochlamydiaceae.

None of the wrasse Chlamydiae have been detected in farmed salmonids (results not shown) and as such they will probably not represent a problem for salmon culture. Movement of wrasse along the Norwegian coast, as cleaner fish in salmon farming, could transmit these bacteria to other wild populations of wrasse. Prevalence of these Chlamydiae in other wrasse populations are, however, unknown, which means that it is not possible to evaluate the consequences of such transmissions.

Acknowledgements. We thank the skilled and dedicated staff at the University of Bergen's Marine Biological Station at Espegrend for providing all fish for our investigations. The open access publication of the present paper was funded by The Norwegian Seafood Research Fund, FHF (project number 901053). 


\section{LITERATURE CITED}

Askeland J (2002) Parasites of ballan wrasse, Labrus bergylta (Labridae), a cleaner fish in salmon pens. MSc thesis, University of Bergen

Bradley TM, Newcomer CE, Maxwell KO (1988) Epitheliocystis associated with massive mortalities of cultured lake trout Salvelinus namaycush. Dis Aquat Org 4:9-17

Brown AMV, Kent ML, Adamson ML (2010) Description of five new Loma (Microsporidia) species in Pacific fishes with redesignation of the type species Loma morhua Morrison \& Sprague, 1981, based on morphological and molecular species-boundaries tests. J Eukaryot Microbiol 57:529-553

Bush RM, Everett KD (2001) Molecular evolution of the Chlamydiaceae. Int J Syst Evol Microbiol 51:203-220

Camus A, Soto E, Berliner A, Clauss T, Sanchez S (2013) Epitheliocystis hyperinfection in captive spotted eagle rays Aetobatus narinari associated with a novel Chlamydiales 16S rDNA signature sequence. Dis Aquat Org 104:13-21

Contador E, Methner P, Ryerse I, Huber P, Lillie BN, Frasca S Jr, Lumsden JS (2016) Epitheliocystis in lake trout Salvelinus namaycush (Walbaum) is associated with a $\beta$ proteobacteria. J Fish Dis 39:353-366

Corsaro D, Work TM (2012) Candidatus Renichlamydia lutjani, a Gram-negative bacterium in internal organs of blue-striped snapper Lutjanus kasmira from Hawaii. Dis Aquat Org 98:249-254

Crespo S, Grau A, Padros F (1990) Epitheliocystis in the cultured amberjack, Seriola dumerili Risso (Carangidae). Aquaculture 90:197-207

* Crosbie PBB, Bridle AR, Cadoret K, Nowak BF (2012) In vitro cultured Neoparamoeba perurans causes amoebic gill disease in Atlantic salmon and fulfils Koch's postulates. Int J Parasitol 42:511-515

Draghi A II, Vsevolod LP, Kahl MM, Stanton JB and others (2004) Characterization of 'Candidatus Piscichlamydia salmonis' (Order Chlamydiales), a Chlamydia-like bacterium associated with epitheliocystis in farmed Atlantic salmon (Salmo salar). J Clin Microbiol 42:5286-5297

Duesund H, Nylund S, Watanabe K, Ottem KF, Nylund A (2010) Characterization of a VHS virus genotype III isolated from rainbow trout (Oncorhynchus mykiss) at a marine site on the west coast of Norway. Virol J 7:19

Einer-Jensen K, Ahrens P, Forsberg R, Lorenzen N (2004) Evolution of the fish rhabdovirus viral haemorrhagic septicaemia virus. J Gen Virol 85:1167-1179

Everett KD, Bush RM, Andersen AA (1999) Emended description of the order Chlamydiales, proposal of Parachlamydiaceae fam. nov. and Simkaniaceae fam. nov., each containing one monotypic genus, revised taxonomy of the family Chlamydiaceae, including a new genus and five new species, and standards for the identification of organisms. Int J Syst Bacteriol 49:415-440

Fehr A, Walther E, Schmidt-Posthaus H, Nufer L and others (2013) Candidatus Sygnamydia venezia, a novel member of the phylum Chlamydiae from the broad nosed pipefish, Sygnathus typhle. PLOS ONE 8:e70853

Greub G (2013) International Committee on Systematics of Prokaryotes. Subcommittee on the taxonomy of Chlamydiae. Minutes of the closed meeting, 23 February 2011, Ascona, Switzerland. Int J Syst Evol Microbiol 63: 1934-1935

Heuch PA, Bjørn PA, Finstad B, Holst JC, Asplin L, Nilsen F (2005) A review of the Norwegian 'National action plan against salmon lice on salmonids': the effect on wild salmonids. Aquaculture 246:79-92

Horn M (2008) Chlamydiae as symbionts in eukaryotes. Annu Rev Microbiol 62:113-131

Isaksen TE (2013) Ichthyobodo infections on farmed and wild fish. Methods for detection and identification of Ichthyobodo spp. PhD thesis, University of Bergen

ㅈaksen TE, Karlsbakk E, Sundnes GA, Nylund A (2010) Patterns of Ichthyobodo necator sensu stricto infections on hatchery-reared Atlantic salmon Salmo salar in Norway. Dis Aquat Org 88:207-214

光Isaksen TE, Karlsbakk E, Watanabe K, Nylund A (2011) Ichthyobodo salmonis sp. n. (Ichthyobodonidae, Kinetoplastida) an euryhaline ectoparasite infecting Atlantic salmon (Salmo salar L.). Parasitology 138:1164-1175

Isaksen TE, Karlsbakk E, Repstad O, Nylund A (2012) Molecular tools for the detection and identification of Ichthyobodo spp. (Kinetoplastida), important fish parasites. Parasitol Int 61:675-683

Johansen R, Bergh Ø, Modahl I, Dahle G, Gjerset B, Holst JC, Sandlund N (2013) High prevalence of viral haemorrhagic septicaemia virus (VHSV) in Norwegian springspawning herring. Mar Ecol Prog Ser 478:223-230

Kabata Z (1992) Copepods parasitic on fishes. Keys and notes for identification of the species. In: Kermack DM, Barnes RSK, Crothers JH (eds) Synopsis of the British fauna, Vol 47. Linnean Society, London \& the Estuarine and Coastal Sciences Association, Oegstgeest

Karlsbakk E, Hodneland K, Nylund A (1996) Health status of goldsinny wrasse, including a detailed examination of the parasite community at Flødevigen, southern Norway. In: Sayer MDJ, Treasurer JW, Costello MJ (eds) Wrasse: biology and use in aquaculture. Fishing News Books, Oxford, p 228-239

Karlsbakk E, Olsen AB, Einen AC, Mo TA and others (2013) Amoebic gill disease due to Paramoeba perurans in ballan wrasse (Labrus bergylta). Aquaculture 412413:41-44

Karlsen M, Nylund A, Watanabe K, Helvik JV, Nylund S, Plarre H (2008) Characterization of Candidatus Clavochlamydia salmonicola: an intracellular bacterium infecting salmonid fish. Environ Microbiol 10:208-218

Katharios P, Seth-Smith HM, Fehr A, Mateos JM and others (2015) Environmental marine pathogen isolation using mesocosm culture of sharpsnout seabream: striking genomic and morphological features of novel Endozoicomonas sp. Sci Rep 5:17609

Kent ML, Elliott DG, Groff JM, Hedrick RP (1989) Loma salmonae (Protozoa: Miscrospora) infections in seawater reared Coho salmon Oncorhynchus kisutch. Aquaculture 80:211-222

K Kim M, Oh HS, Park SC, Chun J (2014) Towards a taxonomic coherence between average nucleotide identity and 16S rRNA gene sequence similarity for species demarcation of prokaryotes. Int J Syst Evol Microbiol 64: 346-351

Krkošek M, Revie CW, Gargan PG, Skilbrei OT, Finstad B, Todd CD (2013) Impact of parasites on salmon recruitment in the Northeast Atlantic Ocean. Proc R Soc B 280: 20122359

Lai CC, Crosbie PBB, Battaglene SC, Nowak BF (2013) Effects of epitheliocystis on serum lysozyme activity and osmoregulation in cultured juvenile striped trumpeter, Latris lineata (Forster). Aquaculture 388-391: 99-104 
Lewis EJ, McLaughlin SM, Bodammer JE, Sawyer TK (1992) Epitheliocystis in ten new host species of marine fish. J Fish Dis 15:267-271

Mendoza M, Güiza L, Martinez X, Caraballo X, Rojas J, Aranguren LF, Salazar M (2013) A novel agent (Endozoicomonas elysicola) responsible for epitheliocystis in cobia Rachycentrum canadum larvae. Dis Aquat Org 106:31-37

* Munro ES, McIntosh RE, Weir SJ, Noguera PA and others (2015) A mortality event in wrasse species (Labridae) associated with the presence of viral haemorrhagic septicaemia virus. J Fish Dis 38:335-341

Müller PY, Janovjak H, Miserez AR, Dobbie Z (2002) Processing of gene expression data generated by quantitative real-time RT-PCR. Biotechniques 32:1372-1379

Nowak BF, LaPatra SE (2006) Epitheliocystis in fish. J Fish Dis 29:573-588

Nylund A, Kvenseth AM, Isdal E (1998) A morphological study of the epitheliocystis agent in farmed Atlantic salmon. J Aquat Anim Health 10:43-55

Nylund A, Watanabe K, Nylund S, Karlsen M, Sæther PM, Arnesen CE, Karlsbakk E (2008) Morphogenesis of salmonid gill poxvirus associated with proliferative gill disease in farmed Atlantic salmon (Salmo salar) in Norway. Arch Virol 153:1299-1309

Nylund S, Nylund A, Watanabe K, Arnesen CE, Karlsbakk E (2010) Paranucleospora theridion n. gen., n. sp. (Microsporidia, Enterocytozoonidae) with a life cycle in the salmon louse (Lepeophtheirus salmonis, Copepoda) and Atlantic salmon (Salmo salar). J Eukaryot Microbiol 57: 95-114

Nylund S, Andersen L, Sævareid I, Plarre H and others (2011) Diseases of farmed Atlantic salmon Salmo salar associated with infections by the microsporidian Paranucleospora theridion. Dis Aquat Org 94:41-57

Nylund S, Steigen A, Karlsbakk E, Plarre H and others (2015) Characterization of 'Candidatus Syngnamydia salmonis' (Chlamydiales, Simkaniaceae), a bacterium associated with epitheliocystis in Atlantic salmon (Salmo salar L.). Arch Microbiol 197:17-25

Page RD (1996) Tree view: an application to display phylogenetic trees on personal computers. Comput Appl Biosci 12:357-358

Paperna I, Sabnai I (1980) Epitheliocystis disease in fish. In: Ahne W (ed) Fish diseases. Third COPRAQ-Session. Springer-Verlag, Berlin, p 228-234

Polkinghorne A, Schmidt-Posthaus H, Meijer A, Lehner A, Vaughan L (2010) Novel Chlamydiales associated with epitheliocystis in a leopard shark Triakis semifasciata. Dis Aquat Org 91:75-81

Posada D, Crandall KA (1998) MODELTEST: testing the model of DNA substitutions. Bioinformatics 14:817-818

Sandlund N, Gjerset B, Bergh Ø, Mohdahl I, Olesen NJ, Johansen R (2014) Screening for viral haemorrhagic septicaemia virus in marine fish along the Norwegian coastal line. PLOS ONE 9:e108529

Schmidt-Posthaus H, Polkinghorne A, Nufer L, Schifferli A and others (2012) A natural freshwater origin for two chlamydial species, Candidatus Piscichlamydia salmonis and Candidatus Chlavochlamydia salmonicola, causing mixed infections in brown trout (Salmo trutta). Environ Microbiol 14:2048-2057

Seth-Smith HM, Dourala N, Fehr A, Qi W and others (2016) Emerging pathogens of gilthead seabream: characterisa- tion and genomic analysis of novel intracellular $\beta$-proteobacteria. ISME J 10:1791-1803

KSnow M, Bain N, Black J, Taupin V and others (2004) Genetic population structure of marine viral haemorrhagic septicaemia virus (VHSV). Dis Aquat Org 61: $11-21$

* Stackebrandt E (2009) Phylogeny based on 16S rRNA/DNA. In: Encyclopedia of Life Sciences (ELS). John Wiley \& Sons

Stackebrandt E, Ebers J (2006) Taxonomic parameters revisited: tarnished gold standards. Microbiol Today 33: 152-155

* Stackebrandt E, Goebel BM (1994) Taxonomic Note: A place for DNA-DNA reassociation and 16S rRNA sequence analysis in the present species definition in bacteriology. Int J Syst Evol Microbiol 44:846-849

Steigen A, Nylund A, Karlsbakk E, Akoll P and others (2013) 'Cand. Actinochlamydia clariae' gen. nov., sp. nov., a unique intracellular bacterium causing epitheliocystis in catfish (Clarias gariepinus) in Uganda. PLOS ONE 8: e66840

Steigen A, Karlsbakk E, Plarre H, Watanabe K, Øvergård AC, Brevik Ø, Nylund A (2015) A new intracellular bacterium, Candidatus Similichlamydia labri sp. nov. (Chlamydiaceae) producing epitheliocysts in ballan wrasse, Labrus bergylta (Pisces, Labridae). Arch Microbiol 197: 311-318

* Stride MC, Polkinghorne A, Miller TL, Groff JM, LaPatra SE, Nowak BF (2013a) Molecular characterization of 'Candidatus Parilichlamydia carangidicola,' a novel Chlamydia-like epitheliocystis agent in yellowtail kingfish, Seriola lalandi (Valenciennes), and the proposal of a new family, 'Candidatus Parilichlamydiaceae' fam. nov. (Order Chlamydiales). Appl Environ Microbiol 79: 1590-1597

* Stride MC, Polkinghorne A, Miller TL, Nowak BF (2013b) Molecular characterisation of 'Candidatus Similichlamydia latridicola gen. nov., sp. nov.' (Chlamydiales: "Candidatus Parilichlamydiaceae"), a novel Chlamydia-like epitheliocystis agent in striped trumpeter, Latris lineata (Forster). Appl Environ Microbiol 79:4914-4920

* Stride MC, Polkinghorne A, Powell MD, Nowak BF (2013c) 'Candidatus Similichlamydia laticola', a novel Chlamydia-like agent of epitheliocystis in seven consecutive cohorts of farmed Australian barramundi, Lates calcarifer (Bloch). PLOS ONE 8:e82889

*Toenshoff ER, Kvellestad A, Mitchell SO, Steinum T, Falk K, Colquhoun DJ, Horn M (2012) A novel betaproteobacterial agent of gill epitheliocystis in seawater farmed Atlantic salmon (Salmo salar). PLOS ONE 7:e32696

* Torrissen O, Jones S, Asche F, Guttormsen A and others (2013) Salmon lice-impact on wild salmonids and salmon aquaculture. J Fish Dis 36:171-194

* Treasurer JW (2012) Diseases of north European wrasse (Labridae) and possible interactions with cohabited farmed salmon, Salmo salar L. J Fish Dis 35:555-562

*Wallace IS, Donald K, Munro LA, Murray W and others (2015) A survey of wild marine fish identifies a potential origin of an outbreak of viral hemorrhagic septicemia in wrasse, Labridae, used as cleaner fish on marine Atlantic salmon, Salmo salar L., farms. J Fish Dis 38:515-521

* Young ND, Dyková I, Snekvik K, Nowak BF, Morrison RN (2008) Neoparamoeba perurans is a cosmopolitan aetiological agent of amoebic gill disease. Dis Aquat Org 78: $217-223$

Submitted: November 12, 2013; Accepted: December 5, 2017 Proofs received from author(s): March 14, 2018 